\title{
INSIGHT IN EDAMAME YIELD AND QUALITY PARAMETERS: A REVIEW
}

\author{
Solvita Zeipiṇa, Ina Alsiṇa, Līga Lepse \\ Latvia University of Agriculture \\ solvita.zeipina@1lu.lv
}

\begin{abstract}
Environmental conditions and climate change on a global scale affect the overall agriculture and food supply. Edamame, also called vegetable soybean is an import vegetable in the world, especially in the East Asia. China is the world's centre for vegetable soybean production. Edamame beans are harvested before full maturity when bean pods are green and just before turning to yellow colour. Most cultivated varieties in the world are of Japanese origin. The aim of this literature survey is to give a review on history and consumption facts of edamame, as well as on the yield and quality parameters of this fresh commodity. Monographic method has been used for this review. Edamame has a high nutritional and medical value. Composition of biologically active compounds in edamame plants is dependent on climate conditions, seasonal changes, cultivar properties and maturity stage. Vegetable soybean has a long cultivation history in the world. In Europe edamame is grown, but in Latvia edamame has not been grown until now, but there is some experience in soya grain growing. Pod colour is the main external quality factor of edamame. It can be influenced by light, moisture, fertilization, variety properties, planting density and harvesting procedures. Vegetation period for edamame in most cases is reported to be between 75 and 100 days.
\end{abstract}

Key words: Glycine max (L.) Merr, pods, quality, protein.

\section{Introduction}

Edamame belongs to the same species as the traditional grain soybean (Glycine max (L.) Merr.). Vegetable soybean has a long history. Glycine soja Sieb \& Zucc in eastern China is the ancestor of Glycine $\max (\mathrm{L}$.$) Merr.). For the first time edamame$ were recorded in China, as early as the second century BC (Mentreddy et al., 2002). Edamame is a traditional component in diet also in Japan, where it has been known for more than 400 years. It is generally sold in the pods as fresh or frozen beans. For consumption, edamame is boiled for 5 to 7 minutes in highly salted water (Johnson, Wang, \& Suzuki, 1999). Edamame, boiled with or without pods, is consumed as snacks, soups, salads or vegetable dishes (Mentredy et al., 2002; Stevenson, Jane, \& Inglet, 2007). In Brazil, edamame packaging is canning; if sucrose is added, it helps to save the desirable colour (Czaikoski et al., 2013).

Soybean is an annual self-pollinated diploid legume (Gurdip, Thomas, \& Carter, 1993). It is a popular crop that is widely consumed worldwide (Song et al., 2013). Soybean can be used as oil bean and as food bean. Soybean varieties with a larger seed size than traditional varieties, harvested at immature stage, also are called edamame (Saldivar et al., 2011). The consumption difference between soybeans and edamame is in the stage of maturity when the beans are harvested. Edamame beans are harvested before full maturity when bean pods are green and just before turning to yellow (Basavaraja, Naidu, \& Salimath, 2005; Hu et al., 2006; Pao et al., 2008). Similarly to dried soybeans, the seeds of edamame are characterized by high nutritional and medicinal value (Konovsky, Lumpkin, \& MeClary, 1994). It is valuable due to high protein, fat, phospholipids, phosphorus, calcium, iron, thiamin, riboflavin, vitamin $\mathrm{E}$, diet fibre and isoflavone content (Basavaraja, Naidu, \& Salimath, 2004; Hu et al., 2006). There are also reports on high level of essential amino acids in the beans (Maruthi \& Paramesh, 2016). Soybean is a good source of several natural isoflavones (78 to $220 \mu \mathrm{g} \mathrm{g}^{-1}$ dried seed) (Mentredy et al., 2002). Isoflavones have a preventive effect on vascular diseases, osteoporosis, menopausal symptoms, and cognitive function (Sirisomboon, Pornchaloempong, \& Romphophak, 2007). Soybean also has potential for cancer prevention and suppression due to its high genistein content (Huang et al., 2014). Clinical studies show that isoflavones in soybean proteins have a positive influence on blood substance and reduce the risk of cardiovascular diseases (Mentredy et al., 2002). Edamame is a valuable food for vegetarians and vegans due to its high nutritional value, especially as a source of proteins and amino acids. Vegetable soybeans are also used in the preparation of innovative products such as green milk, green tofu and green noodles (Basavaraja, Naidu, \& Salimath, 2005).

According to literature, the vegetation period for edamame in most cases is between 75 and 100 days. Such length of vegetation period is common for majority of agricultural crops in Latvia. Taking into account this fact, assumption of too short vegetation period in Latvia is deniable. Nonetheless, the shorter the vegetation period, the more secure is a high quality production outcome. This fact is taken into consideration also by edamame breeders worldwide - the most important breeding objectives are early maturity, high quality (Fig. 1.) and disease and insect resistance (Shanmgasundaram, 1991). Edamame tradability is characterized by physical and organoleptic properties. Quality characteristics depend 


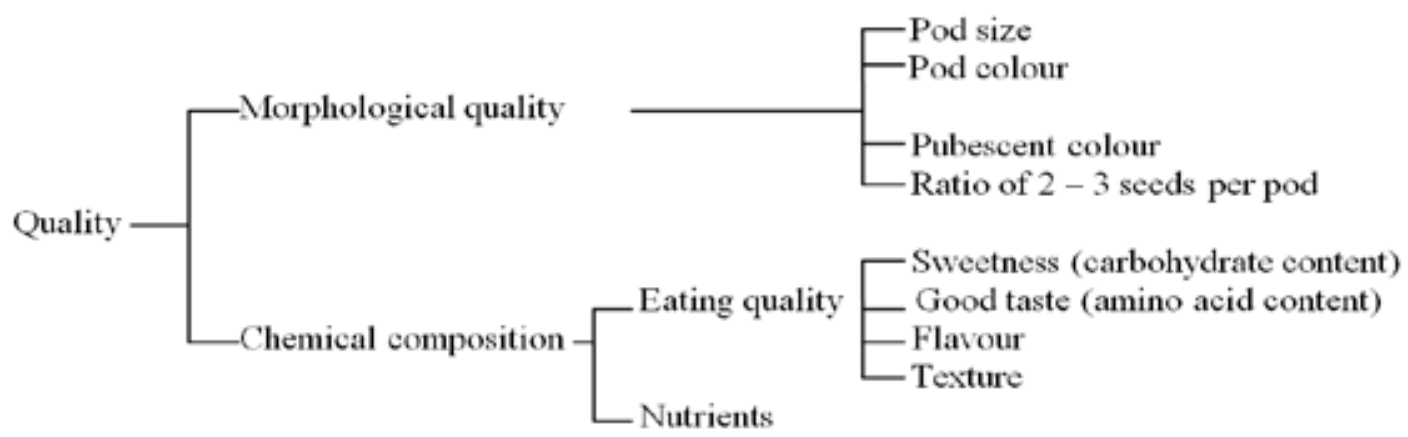

Figure1. Quality components of vegetable soybean (Shanmgasundaram, 1991).

on genotype, harvest time, growth and environmental conditions (Mentreddy et al., 2002).

Quality parameters of vegetable soybean are scaled into five categories, including visual aspects, taste, flavour, texture and nutritional value. The pod colour is crucial and bright-green is the most suitable. Yellowing of the pods shows freshness decrease and debasement of ascorbic acid. At harvest, edamame has more vitamins than field-dried soybeans. Taste is determined by sucrose, glutamic acid and alanine. Sucrose promotes sweetness, while saponin, isoflavonoids, and L-arginine add bitterness to edamame seeds. The blanched beans are mostly used in the human diet. It is found that shortly boiled/ blanched edamame beans are a good source of ascorbic acid, vitamin E and dietary fibre (Shanmgasundaram, 1991; Johnson, Wang, \& Suzuki, 1999). Analysis of vegetable soybean performed in Japan showed energy value $2435 \mathrm{~kJ}$ per $100 \mathrm{~g}$, as well as $71 \mathrm{~g}$ water, 11 g protein, $7 \mathrm{~g}$ lipids, $7 \mathrm{~g}$ carbohydrates, $2 \mathrm{~g}$ fiber, 16 $\mathrm{g}$ dietary fiber, $2 \mathrm{~g}$ ash and $70 \mathrm{mg}$ calcium, $140 \mathrm{mg}$ phosphorus, $140 \mathrm{mg}$ potassium, $27 \mathrm{mg}$ ascorbic acid and also other vitamins and microelements (Johnson, Wang, \& Suzuki, 1999; Wszelaki et al., 2005).

The aim of this literature survey is to give a review on history and consumption facts of edamame, as well as on the yield and quality parameters of this fresh commodity.

\section{Materials and Methods}

Monographic method has been used for this review. Literature from different scientific journals all around the world has been used in its development. It includes information from research conducted in Japan, India, Thailand, Georgia, Pakistan, Canada, Brazil, Dakota, Mississippi and Colorado.

\section{Results and Discussion \\ Growing conditions}

Until harvest, the edamame growing system is similar to that of traditional grain soybeans. However, the edamame seeds are larger and it can be necessary to organize a different sowing system if the sowing machines are used. Seeds have to be sown in $2.5-5.0$ $\mathrm{cm}$ depth, in well-drained, warm, moist fertile soils. Plantlets may be started in a greenhouse and later transplanted in the field. If edamame is sown for the first time in a particular field, the seed should be inoculated with the Rhizobium strain, Bradyrhizobium japonicum bacterium (Konovsky, Lumpkin, \& MeClary, 1994; Kaiser \& Ernst, 2013; Zhang et al., 2013). As planting depth increases, soybean seedling emergence declines (Zhang et al., 2013). Soybean germination will be better if seeds are planted into moist soil (Mentredy et al., 2002). In Japan, base fertilizer rates used for soybean are approximately $50-80 \mathrm{~kg}$ nitrogen $\mathrm{ha}^{-1}$, $70-100 \mathrm{~kg}$ phosphorus, and $100-140 \mathrm{~kg}$ potassium $\mathrm{ha}^{-1}$. Immoderate nitrogen fertilizer can influence pod number and increase the number of empty or oneseeded pods. One of the significant factors influencing yield is the planting density. The distance between rows influences plant development more than distance between plants in a row. Lower plant densities provide darker pods (Kanovsky, Lumpkin, \& MeClary, 1994). Low phosphorus availability can negatively influence edamame growing and development. The biotechnological tool can be used to improve phosphorus using efficiency in vegetable soybean - a rice phosphate transporter gene has to be transferred into the vegetable soybean genome (Yan et al., 2014).

Plant growing and development conditions can influence properties of a particular variety. A major factor for vegetable soybean production is seed quality. In India research was performed with the aim to determine the best nutrient management system for higher seed quality. From 12 different tested treatment combinations the best results showed variants with treatment combination of recommended rates of NPK (30:80:37.5 kg ha-1) + Recommended dose of FYM (farmyard manure), (10 t ha-1) + Bradyrhizobium inoculant $\left(250 \mathrm{~g} \mathrm{ha}^{-1}\right)+$ PSB (phosphate solubilizing bacteria), (250 $\left.\mathrm{g} \mathrm{ha}^{-1}\right)$ can be used for obtaning good quality seeds of vegetable soybean. In all variants, the mean germination rate was $85.4 \%$ (Maruthi \& Paramesh, 2016). There is a high variation found between genotypes according to plant height, yield, 
seed size, seed flavour, and time to maturity (Kaiser \& Ernst, 2013). In India, an investigation was performed with 10 vegetable soybean genotypes, where plants were grown with a spacing of $30 \mathrm{~cm}$ between rows and $10 \mathrm{~cm}$ between plants in a row. In all vegetable soybean genotypes a significant difference was observed between measurements, except pod width. Plant height ranged from 26.7 to $62.73 \mathrm{~cm}$, number of branches $2-3$, period of $35-46$ days to $50 \%$ flowering and $79-84$ days to harvest, pod number on plant was ranged from 22 to 31 , pod length $3.3-4.6$ and pod width $0.9-1.1 \mathrm{~cm}$, the fresh pod yield varied between 6.2 and $11.4 \mathrm{t} \mathrm{ha}^{-1}$ and, accordingly, the seed yield was $2.0-4.9 \mathrm{t} \mathrm{ha}^{-1}$, but hundred seed weight was found to be 16.7 - 35.8 grams. Basavaraja with colleagues observed a positive correlation between seed yield, pod length, and hundred seed weight (Basavaraja, Naidu, \& Salimath, 2005). In Pakistan, an investigation was performed on evaluation of different soybean genotypes, where plants were grown in a spacing of $30 \mathrm{~cm}$ between rows and $5 \mathrm{~cm}$ between plants in a row. The average number of pods per plant was recorded as 21 and average plant height $-71 \mathrm{~cm}$ (Rehman et al., 2014).

In China, 30 edamame genotypes were analyzed. Seeds were sown in a row with $65 \mathrm{~cm}$ spacing. Plant height was varying from 32 to $119 \mathrm{~cm}$ and growing period between 101 - 130 days (Li et al., 2012). Investigation in two different places in Colorado during 1994 - 1998 year showed significant differences in yield, depending on location. The yield of five edible bean cultivars ranged between $2.2-8.1$ in one location and $4.1-10.2 \mathrm{t} \mathrm{ha}^{-1}$ in another, but marketable yield between $1.0-4.8$ in one location and $2.1-6.8 \mathrm{th}^{-1}$ in another (Johnson, Wang, \& Suzuki, 1999). Another investigation was performed in Georgia, US with six edamame cultivars from Japan, two from China and two US elite soybean cultivars during 1995 - 1998. The average fresh green pod yield ranged between 16.3 and $19.7 \mathrm{t} \mathrm{ha}^{-1}$, but seed yield ranged between 7.3 and $11.6 \mathrm{t} \mathrm{ha}^{-1}$ (Mentreddy et al., 2002).

In Brazil, four vegetable soybean genotypes were compared. The number of pods per plant during two vegetation seasons on average fluctuated between 17 and 29. Fresh bean yield was stated to be from 3.3 to $6.6 \mathrm{t} \mathrm{ha}^{-1}$ (Santos et al., 2013).

Five vegetable soybean cultivars were evaluated during 2003 and 2004 in Dakota. Marketable yield in the trial ranged between 6.5 and $11.3 \mathrm{t} \mathrm{ha}^{-1}$ and pod number per plant was $27-81$ (Duppong \& HattermanValenti, 2005). During 2004 and 2005 in Mississippi Zhang and Kyei-Boahen (2007) observed that plant growth and development were faster in 2004 than 2005 because in 2004 there were warmer temperatures at planting (average $25^{\circ} \mathrm{C}$ ). The late-maturing variety plants in the trial were taller, had more pods per plant and total fresh pod weight was higher than for the early-maturing varieties. In 2004, the plant height ranged between $21-74 \mathrm{~cm}$ and in 2005 from 17 to $144 \mathrm{~cm}$; accordingly, pods per plant ranged between $14-57$ and $27-98$, and yield ranged between $1.6-$ 21.4 and $8.5-39.2 \mathrm{t} \mathrm{ha}^{-1}$ respectively in both years.

\section{Harvesting}

In small farms edamame yield is usually harvested by hands. Pods are ready for harvest when they are close to full size and are bright green (between R6 and R7 growth stage), and pods have filled up to $80-90 \%$ of the pod width (Konovsky, Lumpkin, \& MeClary, 1994; Mentreddy et al., 2002; Basavaraja, Naidu, \& Salimath, 2005). It is highly recommended to perform pod cooling during post-harvest to save the product freshness as long as possible (Kaiser, \& Ernst, 2013). Edamame pods at harvest should have white pubescence; the hilum should be light brown or gray. Two or three seeds must be developed in the pod and pod length must be at least $5 \mathrm{~cm}$ and width $1.4 \mathrm{~cm}$ (Metredy et al., 2002). Pods are sorted in two grades. Level A, - at least $90 \%$ pods with two or three seeds. The pods have a good shape, are completely green, and without injury or blots. Level B edamame pods can be a little bit lighter green, and a few pods can be slightly spotted, injured. In both levels, pods cannot be completely mature or unripe, with disease, or insect-damaged. Pod colour is the most seeable quality parameter of edamame (Konovsky, Lumpkin, \& MeClary, 1994; Sirisomboon, Pornchaloempong, \& Romphophak, 2007; Sirisomboon, Hashimato, \& Tanaka, 2009). Ensuring of high quality is quite a challenging task in edamame production. In Thailand, green soybean pods were analyzed with NIR scanning system, all samples were classified into 10 groups of pods. From total pod number (802) only 98 were of good quality. Most of pods had downy mildew (Peronospora manshurica) (167) and brown spots (Septoria glycines) (193) (Sirisomboon, Hashimato, \& Tanaka, 2009).

\section{Yield quality}

Different factors such as cultivar, growing conditions, climate, soil type, and plant maturity can influence the biochemical quality of crop. Not only environmental factors, but also genetic factors can strongly affect the seed biochemical composition. Soybean is an important source of vegetable proteins and lipids, especially of essential fatty acids (Zarkadas et al., 2007). In Japan and Canada, different methods are used for protein quality determination. These methods are used by breeders to select high quality soybean varieties. In Canada, 14 soybean cultivar seeds were analyzed, where average protein content values among these varieties ranged from 29.8 to 
36.1\% (Zarkadas et al., 2007; Lee et al., 2012). Starch content in immature soybean seeds was found to be $4-5 \%$, but it decreased to almost zero at maturity. Level of oil increased rapidly to $20 \%$ at 40 days after flowering, and stayed constant until maturity, but protein was accumulated at later stages. 60 soybean genotypes were analyzed and it was observed that sucrose and raffinose contents were positively correlated with oil content, but negatively correlated with protein content (Saldivar et al., 2011). From trials performed in Pakistan data shows that protein concentration of soybean seeds was significantly affected by planting time. Early planted soybean produced seeds with lower protein (Rehman et al., 2014). Protein content increased by $7-8 \%$ in the period of 20 days before harvest (Stevenson, Jane, \& Inglett, 2007). In Georgia, protein and oil content in dry seeds for different genotypes ranged between 33.3 and $38.6 \%$, and from 5.0 to $6.9 \%$ in fresh seeds. The content of sugar ranged from $6.0 \%$ to $7.4 \%$. The content of total soluble sugar of the fresh green beans is a significant factor that directly affects the organoleptic attribute of seeds (Mentreddy et al., 2002). In China, eight vegetable soybean genotypes were analyzed on biochemical composition. It was found that sucrose concentration ranged between 9.4 and $31.8 \mathrm{mg} \mathrm{g}^{-1}$, which is 78.9 to $93.7 \%$ of the total sugar content; free amino acids ranged between 4.6 and $10.2 \mathrm{mg} \mathrm{g}^{-1}$ dry matter. Vegetable soybean contains 23 free amino acids (Song et al., 2013). In India, biochemical evaluation of 16 edamame genotypes of Taiwan origin was performed. Results of investigation indicate significant genotypic variation for content of vitamin $\mathrm{C}$, from 34.8 to $88.7 \mathrm{mg} 100 \mathrm{~g}^{-1}$ dry seeds. Total phenol content in green seeds ranged from 0.68 to $1.39 \mathrm{mg}$ gallic acid equivalent $\mathrm{g}^{-1}$. Antiradical activity varied from 10 to $25 \%$ (Kumar et al., 2014). In another investigation in India, ten different vegetable soybean genotypes were compared. It was determined that protein content in seeds ranged from 11.6 to 15.3 g $100 \mathrm{~g}^{-1}$ of fresh sample. It should be stressed that regarding protein content, the vegetable soybean has the highest ranking among other legumes. Vitamin C content of vegetable soybean genotypes ranged from 15.90 to $20.85 \mathrm{mg} 100 \mathrm{~g}^{-1}$ (Salmani, Vijayalakshmi, \& Sajjan, 2012).

Researchers observed that $10-14$ day storage in a fridge at $3-5{ }^{\circ} \mathrm{C}$ temperature did not show significant loss in edamame seed quality (Johnson, Wang, \& Suzuki, 1999). On the contrary, others observed that when stored at $5{ }^{\circ} \mathrm{C}$ for 10 days, green colour, content of sucrose, and seed weight gradually decreased. Combination of blanching in boiling water and following freezing is found to be a good way to save the quality of vegetables. However, blanching negatively influences the vegetable quality, texture - they become soft, their colour changes to brown, and the content of nutrients is lower. Steam blanching is better than water blanching because more soluble matters have been lost during water blanching (Saldivar et al., 2010).

\section{Conclusions}

Edamame is becoming more and more popular all over the world, particularly in countries from the United States to Asia. Vegetable soybean is of similar growth and development peculiaries as traditional soybean. Fresh green soybeans have a low oil and

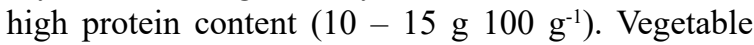
soybean yield and its quality can vary depending on genotype, weather conditions and other environmental and agrotechnological factors.

\section{References}

1. Basavaraja, G.T., Naidu, G.K., \& Salimath, P.M. (2005). Evaluation of vegetable soybean genotypes for yield and component traits. Karnataka Journal of Agricultural Science. 18(1), 27 - 31.

2. Czaikoski, K., Leite, R.S., Gontijo Mandarino, J.M., Carrao-Panizzi, M.C., Silva, J.B., \& Ida, E.I. (2013). Canning of vegetable-type soybean in acidified brine: Effect of the addition of sucrose and pasteurisation time on colour and other characteristics. Industrial Crops and Products. 45, 472 - 476. DOI: 10.1016/j. indcrop.2012.09.009.

3. Duppong, L.M., \& Hatterman-Valenti, H. (2005). Yield and quality of vegetable soybean cultivars for producton in North Dakota. HortTechnology. 15(4), 896 - 900.

4. Kaiser, C., \& Ernst, M. (2013). Edamame. Cooperative extension service. University of Kentucky. 1 - 4.

5. Gurdip, S.B., Thomas, E., \& Carter, J.R. (1993). Soybean. In G. Kallo \& B.O. Bergh (Eds.), Genetic improvement of vegetable crops. (pp. 427 - 464). Oxford: Pergamon Press.

6. Hu, Q., Zhang, M., Mujumdar, A.S., Xiao, G., \& Jincai, S. (2006). Drying of edamame by hot air and vacuum microwave combination. Journal of Food Engineering. 77(4), 977 - 982. DOI: 10.1016/j. jfoodeng.2005.08.025.

7. Huang, M., Wang, Q., Zhang, M., \& Zhu, Q. (2014). Prediction of colour and moisture content for vegetable soybean during drying using hyperspectral imaging technology. Journal of Food Engineering. 128, 24 30. DOI: 10.1016/j.jfoodeng.2013.12.008. 
8. Johnson, D., Wang, S., \& Suzuki, A. (1999). Edamame: a vegetable soybean for Colorado. In J. Janick (Eds.), Perspectives on new crops and new uses (pp. 385 - 387). Alexandria: ASHS Press.

9. Konovsky, J., Lumpkin, T.A., \& MeClary, D. (1994). Edamame: the vegetable soybean. In Understanding the Japanese Food and Agrimarket: a multifaceted opportunity (pp. 173 - 181). Binghamton: Haworth Press.

10. Kumar, V., Rani, A., Goyal, L., Vaishnav, J., Pratap, D., Dixit, A.K., \& Billore, S.D. (2014). Assessment of antioxidant constituents and anti-oxidative properties of vegetable soybean. International Journal of Food Properties. 17, $536-544$.

11. Lee, J.W., Uchikata, T., Matsubra, A., Nakamura, T., Fukusaki, E., \& Bamba, T. (2012). Application of supercritical fluid chromatography/mass spectrometry to lipid profiling of soybean. Journal of Bioscience and Bioengineering. 113(2), 262 - 268. DOI: 10.1016/j.jbiosc.2011.10.009.

12. Li, Y., Du, M., Zhang, O., Wang, G., Hashemi, M., \& Liu, X. (2012). Greater differences exist in seed protein, oil, total soluble sugar and sucrose content of vegetable soybean genotypes (Glycine max (L.) Merrill) in Northeast China. Australian Journal of Crop Science. 6(12), 1681 - 1686.

13. Maruthi, J.B., \& Paramesh, R. (2016). Effect of integrated nutrient management on seed quality of vegetable soybean (Glycine max (L.) Merrill) cv. Karune. Legume Research. 39(4), 578 - 583.

14. Mentreddy, S.R., Mohamed, A.I., Joshee, N., \& Yaav, A.K. (2002). Edamame: A nutritious vegetable crop. In Trends in new crops and new uses (pp. 432 - 438). Alexandria: ASHS Press.

15. Pao, S., Eitinger, M.R., Khalid, M.F., Mebrahtu, T., \& Mullins, C. (2008). Microbiological quality of frozen „edamame” (vegetable soybean). Journal of Food Safety. 28, 300 - 313. DOI: 10.1111/j.17454565.2008.00121.x.

16. Rehman, M., Khalig, T., Ahman A., Wajid, S.A., Rasul, F., Hussain, J., \& Hussain, S. (2014). Effect of planting time and cultivar on soybean performance in Semi - Arid Punjab, Pakistan. Global Journal of Science Frontier Research: D Agriculture and Veterinary. 14(3), 40 - 46.

17. Saldivar, X., Eang, Y.J., Chen, P., \& Hou, A. (2011). Changes in chemical composition during soybean seed development. Food Chemistry. 124(4), 1369 - 1375. DOI: 10.1016/j.foodchem.2010.07.091.

18. Saldivar, X., Wang, Y.J., Chen, P., \& Mauromoustakos, A. (2010). Effect of blanching and storage conditions on soluble sugars content in vegetable soybean. LWT-Food Science and Technology. 43(9), 1368 - 1372. DOI: 10.1016/j.lwt.2010.04.017.

19. Salmani, Z., Vijayalakshmi, D., Sajjan, J.T. (2012). Screening of selected vegetable soybean genotypes for nutrient and antinutrient factors. Journal of Dairing, Foods \& Home Sciences. 31(2), 142 - 145.

20. Santos, J.M., Peixoto, C.P., Rangel, M.A.S., Cruz, T.V., Silva, R.N.A., \& Ledo, C.A.S (2013). Agronomic performance of vegetable soybean genotypes cultivated in the reconcavo baiano, Brazil. Revista Brasileira de Ciências Agrárias (Agrária). 8(3), 402 - 407. DOI: 10.5039/agraria.v8i3a2441.

21. Shanmgasundaram, S. (1991). Vegetable soybean: research needs for production and quality improvement. In: Proccedings of a workshop held at Kenting, Taiwan. Asian Vegetable Research and Development Center, $150 \mathrm{p}$.

22. Sirisomboon, P., Hashimato, Y., \& Tanaka, M. (2009). Study on non-destructive evaluation methods for defect pods for green soybean processing by near-infrared spectroscopy. Journal of Food Engineering. 93(4), 502 - 512. DOI: 10.1016/j.jfoodeng.2009.02.019.

23. Sirisomboon, P., Pornchaloempong. P., \& Romphophak, T. (2007). Physical properties of green soybean: criteria for sorting. Journal of Food Engineering. 79(1), 18 - 22. DOI: 10.1016/j.jfoodeng.2006.01.022.

24. Song, J., Liu, C., Li, D., \& Gu, Z. (2013). Evaluation of sugar, free amino acid, and organic acid compositions of different varieties of vegetable soybean (Glycine max (L.) Merr). Industrial Crops and Products. 50, 743 - 749. DOI: 10.1016/j.indcrop.2013.08.064.

25. Stevenson, D.G., Jane, J., \& Inglett, G.E. (2007). Structures and physicochemical properties of starch from immature seeds of soybean varieties (Glycine $\max ($ L.) Merr.) Exhibiting normal, low-linolenic or low-saturated fatty acid oil profiles at maturity. Carbohydrate Polymers. 70(2), 149 - 159. DOI: 10.1016/j. carbpol.2007.03.016.

26. Wszelaki, A.L., Delwiche, J.F., Walker, S.D., Liggett, R.E., Miller, S.A., \& Kleinhenz, M.D. (2005). Consumer liking and descriptive analysis of six varieties of organically grown edamame-type soybean. Food Quality and Preference. 16(8), 651 - 658. DOI: 10.1016/j.foodqual.2005.02.001.

27. Yan, W., Chen, G., Yang, L., Gai, J., \& Zhu, Y. (2014). Overexpression of the rice phosphate transporter gene OsPT6enhances tolerance to low phosphorus stress in vegetable soybean. Scientia Horticulturae. $177,71-76$. 
28. Zarkadas, C.G., Gagnon, C., Gleddie, S., Khanizadeh, S., Cober, E.R., \& Guillemette, R.J.D. (2007). Assesment of the protein quality of fourteen soybean (Glycine max (L.) Merr.) cultivars using amino acid analysis and two-dimensional electrophoresis. Food Research International. 40(1), 129 - 146. DOI: 10.1016/j.foodres.2006.08.006.

29. Zhang, L., \& Kye-Boahen, S. (2007). Growth and yield of vegetable soybean (edamame) in Mississippi. HortTechnology. 17(1), $26-31$.

30. Zhang, Q.Y., Hashemi, M., Hebert, S.J., \& Li, Y.S. (2013). Different responses of preemergence and early seedling growth to planting depth between vegetable soybean and grain soybean. Legume Research. 36(6), $515-521$ 